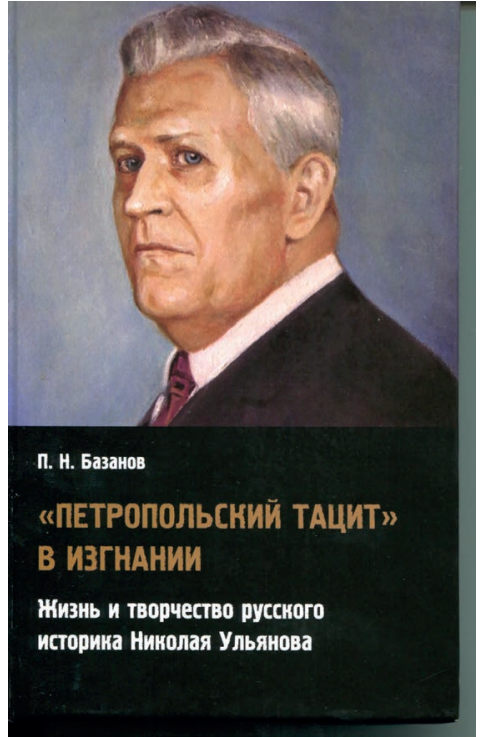

М.Е. Бабичева (Москва, Россия)

Нерукотворный памятник на родине. Базанов П.Н. «Петропольский Тацит» в изгнании. Жизнь и творчество русского историка Николая Ульянова. СПб.: Владимир Даль, 2018. 511 с.

Maya Babicheva (Moscow, Russia)

\title{
Bazanov P.N. «Petropol Tacitus» in Exile. The Life and Work of the Russian Historian Nikolay Ulyanov. St.-Petersburg: Vladimir Dal, 2018. 511 p.
}

Книга П.Н. Базанова о жизни и деятельности Н.И. Ульянова (1904-1985) - peзультат кропотливого высокопрофессионального исследования, продолжавшегося без малого три десятилетия. Автор монографии - доктор исторических наук, профессор Санкт-Петербургского института культуры пишет о своем выдающемся земляке и коллеге, ставшем одной из самых ярких фигур второй волны русской эмиграции. Это первый опыт полного и всестороннего освещения непростой судьбы и богатого творческого наследия Н.И. Ульянова. Структура книги отражает комплексный подход автора к изучению поставленных вопросов. Основу монографии составили две главы, названия которых точно раскрывают содержание каждой из них: «Глава 1. Биография Н.И. Ульянова» и «Глава 2. Основные направления творческой и научной деятельности Н.И. Ульянова». Центральным главам предшествует краткое «Предисловие» и обстоятельный обзор уже имеющихся исследований в данной области, а также документов и материалов, посвященных данному вопросу («Историография и источники»). Завершает книгу составленный автором библиографический указатель публикаций Н.И. Ульянова и литературы о нем.

В «Предисловии» четко и конкретно охарактеризован объект исследования, определены цели и задачи автора.

Обзор историографии и источников заслуживает особо пристального внимания. Здесь задан алгоритм дальнейшего повествования, наглядно показана методика построения текста. Эта часть книги дает полное основание утверждать, что к работе самого П.Н. Базанова вполне применимы цитируемые им слова, сказанные П.А. Муравьевым об Н.И. Ульянове: «...выносить суждения вне прочных данных, не опираясь на серьезную документацию, было не в его характере» (стр. 240). Исследователь собрал, проанализировал и систематизировал около шестисот публикаций, касающихся жизни и творчества Н.И. Ульянова. В монографии наглядно 
показана степень изученности вопроса, дискуссионные аспекты и требующие заполнения лакуны. Названы авторы, внесшие, по мнению П.Н. Базанова, большой вклад «в популяризацию творческого наследия Н.И. Ульянова», а также исследователи, опиравшиеся на редкие архивные материалы. Тактично, но достаточно жестко указано на конкретные недостатки отдельных статей.

П.Н. Базанов пишет о множестве интереснейших документов и материалов, касающихся биографии Н.И. Ульянова, отмечает, что они постепенно публикуются (в том числе при его активном содействии), указывает архивы и коллекции, где эти материалы находятся.

В монографии рассмотрены также переиздания в России работ Н.И. Ульянова. В поле зрения автора их более сотни, однако большая часть этих публикаций вызывает у него серьезные и обоснованные нарекания (отсутствие справочного аппарата, сокращения, искажающие текст, замена названий и т. д.).

Первая из двух «основных» глав монографии - обстоятельный, написанный с опорой на широкую документальную базу биографический очерк. Этот текст одновременно самодостаточен и тесно сопряжен со следующей главой. Факты биографии Н.И. Ульянова органично связаны в нем с его научной и творческой деятельностью. Жизнь ученого прослежена детально, в мельчайших подробностях, для каждого приведенного факта указываются в подстрочных ссылках источники, где о нем говорится. Таким образом, сразу же показаны суть и причины разногласий, существующих в современной науке по поводу отдельных событий жизни Н.И. Ульянова. Целый ряд значимых для своего «героя» событий П.Н. Базанов восстанавливает непосредственно по архивным материалам и впервые вводит в научный оборот.

Жизненный путь Н.И. Ульянова представлен в монографии в широком историческом контексте. П.Н. Базанов, также опираясь на документальные источники и архивные материалы, рассказывает о множестве реалий и малоизвестных современному читателю деталей советской действительности 1920-1940-х гг. и жизни русской диаспоры в послевоенные годы. В биографической главе подробно рассказывается о выдающихся исторических личностях, сыгравших важную роль в судьбе Н.И. Ульянова. Кроме того, приводятся краткие справки-характеристики упоминаемых деятелей науки, искусства, культуры и политиков. Они даются в подстрочных сносках, но обозначены не цифрой, как цитаты, а звездочкой.

Текст главы разделен на тринадцать подглавок, и в каждой представлен один из этапов жизненного пути героя. Они расположены в хронологическом порядке и имеют заголовки, отражающие период жизни («Детство», «Студенческие годы», «Аспирантура»), место нахождения в определенный период («Архангельск», «Марокко», «Нью-Йорк и Канада»), главное событие этого периода («Театральная юность (школа и Курмасцеп»), «Ленинград: наука и преподавание», «Арест и лагерь») или историческую сущность соответствующего этапа («В годы Великой Отечественной войны», «Дипийский период»).

Биографическая глава в данной монографии удачно сочетает характеристики полноценного научного исследования, с одной стороны, и остросюжетной повести, с другой. Сама судьба Н.И. Ульянова, по словам автора, вынесенным на обложку книги, «напоминает захватывающий приключенческий роман, где многочисленные пребывания в неволе чередуются с отчаянными побегами и жизнью в подполье, а аресты на родине - с преподавательским триумфом в Йеле». П.Н. Базанову удалось строгое следование множеству документов и обильное их цитирование соединить с живым эмоциональным рассказом об удивительном человеке, 
создав тем самым исторически достоверный и в то же время емкий и полнокровный образ Н.И. Ульянова. Полностью процитировав стихотворение поэта Юрия Милославского, написанное в Соловецком лагере и посвященное Н.И. Ульянову, П.Н. Базанов объясняет читателю смысл названия всей книги. Рассказывая об обширной переписке, которую вел Н.И. Ульянов, уже живя в Америке, автор монографии приводит «шуточное письмо из Флориды, написанное в традициях отечественных историков под древнерусскую грамоту» (стр. 220). Адресованное В.Г. Вернадскому, это послание придает новые живые грани созданному П.Н. Базановым образу. Очень удачным для обогащения этого образа представляется также заключительная фраза подглавки «Детство». Резюмируя сказанное о дискуссии в науке по поводу места рождения Н.И. Ульянова, исследователь пишет: «Какое место считал своей основной малой родиной, не столь уж принципиально важно, ибо Родина у Николая Ивановича Ульянова всегда была одна - Россия» (стр. 44).

Вторая глава посвящена анализу научного и творческого наследия Н.И. Ульянова. Пять составивших ее очерков раскрывают многоплановую активность в сфере науки, культуры, просвещения. В очерке «Издательская и публицистическая деятельность» детально охарактеризованы основные русские эмигрантские издательства и периодические издания, с которыми сотрудничал Н.И. Ульянов. Это «Издательство им. Чехова» в Нью-Йорке (1952-1956), издательство книжного магазина В.П. Камкина в Вашингтоне (1956-1975), издательство «Посев» (с 1945 г. в лагере Менхегоф, с 1952 г. во Франкфурте-на-Майне, с 1992 г. по настоящее время - в Москве) и издательство «Эрмитаж» (основано в 1981 г. в городе Анн Арбор, штат Мичиган, в 1984 г. переведено в город Тенефлай, штат Нью-Джерси, с 2005 г. по настоящее время находится в Пенсильвании). П.Н. Базанов прослеживает историю публикации этими изданиями произведений Н.И. Ульянова. Исследователь указывает при этом, что другие «эмигрантские издательства крайне неохотно печатали нетривиально мыслящего ученого» (стр. 241).

Интересна приведенная в монографии информация из письма вдовы Н.И. Ульянова П.Н. Базанову, находящегося в личном архиве адресата. Несмотря на значительный размер текста, один отрывок этого письма целесообразно воспроизвести целиком: «С 1970 г. Н.И. Ульянов на обороте титульного листа всех своих книг ставит издательство “Киннипиак”, - пишет П.Н. Базанов. - По свидетельству его вдовы Надежды Николаевны Ульяновой, такого издательства не было: “Киннипиак - маленькая речушка недалеко от нашего дома <... . Ее индейское название понравилось Н.И., и он решил сохранить это слово. Впоследствии от писателей получал запросы об адресе издательства, и это веселило его"» (стр. 260-261).

Столь же скрупулезно исследует П.Н. Базанов историю публикаций Н.И. Ульянова в эмигрантской периодике. Он отмечает, что работы этого автора печатались во многих газетах и журналах, вызывая многочисленные отклики и бурные полемики. В то же время, указывает исследователь, «только три ведущих периодических издания русской эмиграции, где он постоянно публиковался, считали его своим сотрудником: “Возрождение", "Новый журнал” и "Новое русское слово” (стр. 265). Подробно рассказывая о каждом из этих изданий, П.Н. Базанов создает контекст, в котором следует рассматривать публицистическую деятельность Н.И. Ульянова. При этом называет точное число его публикаций и откликов на них в каждом из указанных изданий.

Отдельный очерк - «Философия истории» - П.Н. Базанов посвятил историософским взглядам своего героя. Здесь показано место ученого в противостоянии двух основных тенденций в исторической науке: установки на выявление всеоб- 
щих закономерностей, с одной стороны, и «гегемонии исторического факта», с другой. Активный сторонник последней, Н.И. Ульянов величайшими «обобщателями» называл марксистов, глубоко чуждых ему идейно. Ученый отрицал идею линейного прогресса, считая ее классическим переносом политики в науку. Анализируя работы по этому вопросу Н.И. Ульянова, его единомышленников и оппонентов, П.Н. Базанов приходит к выводу, что Н.И. Ульянов во многом предвосхищает взгляды современных ученых на исторический процесс и историю культуры. «Кроме научной стороны, - отмечает исследователь, - история у Н.И. Ульянова трактуется как специфический вид духовного творчества, своеобразный мост между искусством и точными науками» (стр. 298).

Центральным во второй главе книги П.Н. Базанова стал очерк «Национальный вопрос и феномен украинского сепаратизма в творчестве Н.И. Ульянова». Здесь представлены работы ученого, составившие его основной вклад в русскую академическую науку. В первую очередь, это монография «Происхождение украинского сепаратизма». Приводится подробный анализ этого актуальнейшего на текущий момент монументального труда. Рассматриваются также «примыкающие» к этой монографии по тематике произведения Н.И. Ульянова самых разных жанров: статьи, эссе, рецензии и т. д. П.Н. Базанов резюмирует: «Во всех своих работах Н.И. Ульянов убедительно доказывает, что главный чертой украинского самостийного мифотворчества является совершенно беззастенчивая фальсификация лингвистическая, этнографическая, историческая, антропологическая, экономическая и даже филологическая» (стр. 312). Цитируя Н.И. Ульянова, П.Н. Базанов неоднократно выделяет отдельные слова и фразы, подтверждающие особенно важные, с его точки зрения, положения. Он в полном смысле слова наглядно показывает, что Н.И. Ульянов фактически ставил знак равенства между украинским сепаратизмом и немецким нацизмом, видел в нем угрозу для самого существования великороссов и считал жизненно важным для последних этому движению противостоять. Н.И. УЛьянов считал великороссов, малороссов и белорусов единой этнокультурной общностью. Русскую культуру он рассматривал как единственную подлинную духовную скрепу, способную обеспечить сосуществование различных народов в рамках одного государства. Поэтапно рассмотрев все стадии возникновения и становления украинского сепаратизма, Н.И. Ульянов очень точно охарактеризовал его сущность, что подтверждается событиями последних лет на Украине. Особо подчеркивает П.Н. Базанов публицистический пафос работы Н.И. Ульянова. Он называет очень удачным определение этой книги, данное современным публицистом Л.М. Аринштейном: «Перед нами монументальный научный труд и политический памфлет, слитые воедино» (стр. 310).

Еще один очерк в монографии П.Н. Базанова - «Интеллигенция в творчестве Н.И. Ульянова». Рассматривая посвященные этому вопросу работы ученого, в первую очередь статью «Ignorantia Est», автор монографии выделяет два аспекта, вызвавших дискуссию. Во-первых, Н.И. Ульянов именно на интеллигенцию возлагал моральную ответственность за сталинский террор, направленный, по его мнению, не на нее саму, а главным образом, на весь русский народ. Во-вторых, он подверг сомнению декларируемую интеллигенцией любовь к народу, отметил свойственное ей презрение к «простым» людям. В работах Н.И. Ульянова, показывает П.Н. Базанов, не сразу было четко сформулировано, кого именно он называет «интеллигентами». В статье «Интеллигенция» он разграничил просвещенных интеллектуалов России, с одной стороны, и революционную радикальную интеллигенцию, к которой относятся его обвинения в отсутствии культуры, 
обскурантизме и все негативные оценки, с другой. В монографии показана бурная полемика, вызванная работами Н.И. Ульянова.

Завершает книгу очерк «Культура в творчестве Н.И. Ульянова». Разным аспектам этого вопроса ученый посвятил целый ряд работ, показывает П.Н. Базанов. Он отмечает: «Для Н.И. Ульянова культура является главным критерием существования народа и самоопределения личности» (стр. 370). Н.И. Ульянов считал, что революция неизбежно приводит к деградации культуры, поскольку культура и этика в принципе непримиримы. В то же время техника, в его понимании, равноправная с искусством часть культуры. Большое внимание уделял Н.И. Ульянов культуре русской эмиграции. Он был сторонником сохранения и развития русской культуры за рубежом, высоко ценил деятельность в этом направлении представителей первой волны русской эмиграции, но предсказывал постепенное угасание такой функции у диаспоры. 3олотой и Серебряный век русской культуры Н.И. Ульянов называл «восьмым чудом света», но считал их невозможными без реформ, проведенных в свое время Петром I. Он резко опровергал взгляды П.А. Чаадаева, оспаривал основные постулаты славянофилов и евразийцев. Русскую культуру Н.И. Ульянов считал результатом длительного взаимопроникновения культур всех населявших империю народов. Как философ культуры Н.И. Ульянов выступал с темой ее грядущего апокалипсиса и гибели всей человеческой цивилизации. При этом свое поколение он считал последним, способным почувствовать ужас грядущей катастрофы.

Самостоятельную научную ценность имеет вынесенный в приложение биоблиографический указатель «Николай Иванович Ульянов», составленный автором. Это полный свод публикаций ученого на русском и иностранных языках и литературы о нем, известных к настоящему времени. Указатель содержит 590 позиций, материал сгруппирован по разделам, внутри каждого раздела - по хронологии. Пять первых разделов включают публикации самого Н.И. Ульянова. Это «Советский период», «Эмигрантский период», «Посмертные публикации», а также «Работы Н.И. Ульянова, уничтоженные при аресте в 1936 г.» и «Работы, приписываемые Н.И. Ульянову». Далее следует раздел «О жизни и творчестве Н.И. Ульянова», затем «Диссертации», в которых рассматриваются его произведения, и наконец «Библиографические источники». Последний составили библиографические указатели, включающие материалы, не вошедшие в предыдущие разделы». Не просмотренные составителем визуально издания отмечены звездочкой. В случаях, когда библиографическое описание не соответствует реальным проверенным данным, указывается источник информации.

Биографическую главу книги П.Н. Базанов завершил рассказом о месте захоронения Н.И. Ульянова в США, на старинном кладбище Йельского университета. Он приводит полностью четверостишье Г. Иванова о России, ставшее эпитафией на обелиске русскому историку далеко за океаном. Книга П.Н. Базанова об Н.И. Ульянове - это не только блестящее научное исследование и интереснейшее биографическое повествование, но еще и достойный нерукотворный памятник ученомуэмигранту на родной земле.

Сведения об авторе:

Майя Евгеньевна Бабичева,

канд. филолог. наук

ведущий научный сотрудник

Российская государственная библиотека
Maya Babicheva,

$\mathrm{PhD}$

Leading Researcher

Russian State Library

babichevame@rsl.ru 